\title{
No loss of sst receptors gene expression in advanced stages of colorectal cancer
}

\author{
V Vuaroqueaux ${ }^{1}$, A Dutour ${ }^{1,2}, \mathrm{~N}$ Briard $^{1}$, G Monges ${ }^{3}$, M Grino $^{1}$, C Oliver $^{1,2}$ and L'H Ouafik ${ }^{4}$ \\ ${ }^{1}$ Laboratoire des Interactions Fonctionnelles en Neuroendocrinologie, INSERM U 501, Institut Jean-Roche, UER de Medecine secteur Nord, Bvd Pierre \\ Dramard, 13916 Marseille Cedex 20, France, ${ }^{2}$ Service d'Endocrinologie, Maladies Métaboliques et de la Nutrition, Hôpital Nord, Chemin des \\ Bourrely, 13915 Marseille Cedex 20, France, ${ }^{3}$ Laboratoire d'Anatomopathologie, UER de Medecine secteur Timone, Marseille, France and \\ ${ }^{4}$ Laboratoire de Cancérologie Experimentale, Institut Jean-Roche, UER de Medecine secteur Nord, Bvd Pierre Dramard, 13916 Marseille Cedex 20, \\ France
}

(Correspondence should be addressed to A Dutour at Service d'Endocrinologie, Maladies Métaboliques et de la Nutrition, Hôpital Nord, Chemin des Bourrely, 13915 Marseille Cedex 20, France)

\begin{abstract}
As demonstrated by several studies, the pan-inhibitory peptide somatostatin (SS) is implicated in a large variety of physiological processes in the gastrointestinal tractus. SS inhibits hormonal and gastric acid secretions, and decreases gastric and intestinal motility, mesenteric blood flow and intestinal absorption. In vitro and in vivo studies showed also that the antiproliferative potency of SS analogs may be a target to improve the prognosis of colorectal cancer. Here we report the expression profile of the five SS receptor subtypes (hsst1-5) mRNAs in a large set of tumoral and normal colon. Using reverse transcription-PCR, we showed that hsst5, hsst1 and hsst 2 mRNA subtypes were the most frequently expressed hsst mRNA subtypes in normal and pathological colon. Interestingly, we found that the frequency of hsst 5 mRNA expression in the left colon was significantly higher in tumors than in normal samples: $81.2 \%(13 / 16)$ and $36.4 \%(4 / 11)$ respectively $\left(0.025>P>0.01, \chi^{2}\right.$ test with Yates' correction). We did not find any influence of Dukes' stage on hsst mRNAs expression. Of interest, no loss of hsst 2 and hsst5 mRNA expression in advanced stages was noted. Some differences in the frequency of expression of hsst mRNAs according to the origin of the tissue (left or right colon) were evident. The expression of hsst 5 and hsst 2 mRNA in advanced colorectal carcinoma associated with the development of new SS analogs boost the relevance of colorectal cancer treatment by somatostatin analogs.
\end{abstract}

European Journal of Endocrinology 140 362-366

\section{Introduction}

Despite progress in cancer treatment, colorectal cancer remains one of the most important public health problems. For the advanced stages, the failure of conventional therapies to improve the prognosis of patients needs urgent alternative approaches. A new treatment modality may involve the use of analogs of the ubiquitous pan-inhibitory peptide somatostatin (SS). In the gastrointestinal tract, SS inhibits hormone secretion and gastric acid secretion, and decreases gastric and intestinal motility, mesenteric blood flow and intestinal absorption (1). In addition, SS can inhibit cell proliferation in a wide variety of cell types. The antiproliferative effects of SS are mediated both indirectly through inhibition of the release of various hormones and growth factors which promote cell growth, through inhibition of angiogenesis, and directly through SS receptors located on tumor tissue inducing an inactivation of growth factors or an activation of programmed cell death $(2,3)$. SS and its analogs inhibit in vivo and in vitro tumoral colon cell proliferation and metastatic development $(4,5)$. However, patients with advanced colorectal cancer treated with SS analogs did not present significant benefits although their tumoral markers decreased $(6,7)$.

The actions of SS are mediated via membrane-bound receptors coupled to GTP binding protein. Five SS receptors of seven transmembrane domains termed hsst $1-5$ have been cloned (3). They are all negatively coupled to adenylate cyclase and can also modulate guanidylate cyclase, calcium or potassium channels, activate protein phosphatase, transmodulate tyrosine kinase type receptors and act on the mitogen activated protein kinase (MAP kinase) signaling pathway and even induce apoptosis $(3,8)$.

Binding assays and autoradiographic studies have shown the presence of hsst in most hormone-producing tumors as well as in lymphomas and adenocarcinomas originating from breast, prostate, ovary, kidney or colon. 
In the case of colic tissue, hsst mRNA subtypes have been found in normal and tumoral mucosa, nerve plexus, lymphoid tissue and peritumoral veins (9-12). A few recent studies have attempted to characterize the pattern of expression of the different hsst mRNA subtypes in colic tumors and have given controversial results. Using reverse transcriptase-polymerase chain reaction (RT-PCR), Buscail et al. (13) found an heterogeneous expression of hsst1-hsst5 mRNA in colorectal cancer with a loss of hsst 2 mRNA expression in advanced stages, which could explain partially the lack of effect of SS analogs in clinical trials. Using both RT-PCR and in situ hybridization, Laws et al. (14) found a retained expression of hsst 2 mRNA but a decreased expression of hsst $5 \mathrm{mRNA}$ in late stage tumors.

In order to bring further insight into the pathophysiological basis of the use of SS analogs in colorectal cancer treatment, we reassessed, using RT-PCR, hsst mRNA subtypes expression in a large set of tumoral samples and normal tissues.

\section{Materials and methods}

\section{Materials}

Fifty-three samples of colorectal cancers (primary tumor) and forty-six morphologically normal mucosae (taken from the same patient at a minimal distance of $5 \mathrm{~cm}$ from the diseased area) were obtained during surgery and frozen in liquid nitrogen. All patients gave their written consent to participate in the study which was approved by the local ethics committee (Marseilles I). Colon carcinomas were staged according to the Dukes' classification system (15) (stage A, 12 patients; stage B, 10; stage C, 19; stage D, 12); staging, tumor grade (1 hyperdifferentiated, 42 well differentiated, 7 moderately differentiated, 3 undifferentiated) and tumor site ( 23 rectum, 16 left colon, 14 right colon) are shown in Table 1. Immunohistological study of epidermal growth factor receptors (EGF-R) was performed (ab-2, Calbiochem, La Jolla, CA, USA): ++ corresponds to a high level of EGF-R + corresponds to a moderate level, and \pm corresponds to a low level of EGF-R. Ki67 immuno-detection (Dako, Copenhagen, Denmark) is given as a percentage of positive nuclei. Mutations of the apoptotic protein P53 were detected with 3 monoclonal anti-P53 antibodies (MAB 1801, Calbiochem; MAB 240, Novocastra (Newcastle, UK); DO7, ab-1, Novocastra) (Table 1).

\section{RNA extraction and reverse transcription}

Total RNA was isolated as described by Chomczynsky and Sacchi (16). Since the somatostatin receptor genes lack intronic sequences, the RNA $(10 \mu \mathrm{g})$ was treated with $10 \mathrm{U}$ RNase free DNase I-RQI (Promega, Madison, WI, USA) for $2 \mathrm{~h}$ at $37^{\circ} \mathrm{C}$. RT reaction was performed as described by the manufacturer (Life Technologies,
Gaithersburg, MD, USA). Briefly, each sample was split in one positive reaction with reverse transcriptase and one control reaction without reverse transcriptase to check for DNA contamination.

\section{Polymerase chain reaction}

RNA integrity was verified by co-amplification of the hsst with the constitutively expressed cyclophilin mRNA. Each primer couple was used at $1 \mu \mathrm{mol}$ final concentration, with $200 \mu \mathrm{mol}$ of each dNTP and $200 \mathrm{U}$ Expand long template PCR system polymerase (Boehringer, Mannheim, Germany) in $50 \mu \mathrm{l} 1 \times$ manufacturer's buffer. Optimal temperature and cycling conditions were as follows.

hsst1: denaturing at $95^{\circ} \mathrm{C}$ for $5 \mathrm{~min}$ followed by 35 cycles of annealing at $65^{\circ} \mathrm{C}$ for $90 \mathrm{~s}$ and extension at $72^{\circ} \mathrm{C}$ for $120 \mathrm{~s}$; sense: $129-150$; antisense: $1122-$ 1100; PCR product: $993 \mathrm{bp}$. hsst2: denaturing at $95^{\circ} \mathrm{C}$ for $5 \mathrm{~min}$ followed by 35 cycles of annealing at $62^{\circ} \mathrm{C}$ for $90 \mathrm{~s}$ and extension at $72^{\circ} \mathrm{C}$ for $120 \mathrm{~s}$; sense: $480-498$; antisense: 1372-1355; PCR product: $892 \mathrm{bp}$. hsst3: denaturing at $95^{\circ} \mathrm{C}$ for $5 \mathrm{~min}$ followed by 45 cycles of annealing at $70{ }^{\circ} \mathrm{C}$ for $90 \mathrm{~s}$ and extension at $72{ }^{\circ} \mathrm{C}$ for $120 \mathrm{~s}$; sense: 308-329; antisense: 961-940; PCR product: $653 \mathrm{bp}$. hsst 4 : denaturing at $95^{\circ} \mathrm{C}$ for $5 \mathrm{~min}$ followed by 45 cycles of annealing at $64^{\circ} \mathrm{C}$ for $90 \mathrm{~s}$ and extension at $72{ }^{\circ} \mathrm{C}$ for $120 \mathrm{~s}$; sense: $139-156$; antisense: 1173-1155; PCR product: $1034 \mathrm{bp}$. hsst5: denaturing at $95^{\circ} \mathrm{C}$ for $5 \mathrm{~min}$ followed by 35 cycles of annealing at $70{ }^{\circ} \mathrm{C}$ for $60 \mathrm{~s}$ and extension at $72^{\circ} \mathrm{C}$ for $120 \mathrm{~s}$; sense: 647-668; antisense: 1228-1204; PCR product: $581 \mathrm{bp}$.

PCR products were resolved on 1\% agarose gels, stained with ethidium bromide and visualized by UV transillumination (Fig. 1). Specificity of the PCR product was confirmed by Southern blotting and hybridization with the corresponding cDNAs as previously described (17). All samples were tested for DNA contamination. PCR samples positive without reverse transcriptase treatment were systematically discarded from the study.

Statistical analysis was performed using the $\chi^{2}$ test with Yates' correction.

\section{Results}

We found that $85 \%$ of normal tissues and $97 \%$ of tumors expressed at least one hsst mRNA subtype. The subtypes hsst5, hsst 2 and hsst 1 were the more frequently expressed, respectively at $68.6 \%, 54.7 \%$ and $56.6 \%$ in the tumoral samples and at $48.8 \%, 60.8 \%$ and $41.3 \%$ in the normal tissues (Table 2). hsst 3 and hsst 4 mRNA subtypes were less frequently expressed both in tumors, at $15.2 \%$, and $16.9 \%$ respectively and in normal tissues at $17.9 \%$ and $8.7 \%$ respectively. We did not find any influence of Dukes' stages on the hsst mRNAs expression profile. Furthermore, there was no loss of hsst 2 mRNA expression in the advanced 
Table 1 Histopathological and immunohistological study of the tumors.

\begin{tabular}{|c|c|c|c|c|c|c|c|c|}
\hline $\begin{array}{l}\text { Tumor } \\
\text { number }\end{array}$ & $\begin{array}{c}\text { Age } \\
\text { (years) }\end{array}$ & Sex & Stage* & Grade $†$ & Site & EGF-R $\ddagger$ & P53§ & Ki67(\%)\# \\
\hline 1 & 84 & $\mathrm{~F}$ & A & WD & $\operatorname{Rec}$ & + & $-1-1-$ & 25 \\
\hline 2 & 60 & $\mathrm{~F}$ & A & WD & $\operatorname{Rec}$ & + & $+I+1+$ & nd \\
\hline 3 & 78 & $\mathrm{~F}$ & A & WD & $\operatorname{Rec}$ & nd & & nd \\
\hline 4 & 76 & M & A & MD & $\operatorname{Rec}$ & + & $-1-1-$ & 25 \\
\hline 5 & 75 & $\mathrm{~F}$ & A & WD & $\operatorname{Rec}$ & - & $-1-1-$ & $<5$ \\
\hline 6 & 70 & M & A & HD & $\operatorname{Rec}$ & + & $+1+1+$ & $<5$ \\
\hline 7 & 72 & M & A & WD & LC & - & $-1-1-$ & 5 \\
\hline 8 & 66 & $\mathrm{~F}$ & A & WD & LC & nd & $+1+1+$ & $<5$ \\
\hline 9 & 73 & M & A & WD & $\mathrm{RC}$ & ++ & $-1-1-$ & 5 \\
\hline 10 & 60 & $\mathrm{~F}$ & A & WD & $\mathrm{RC}$ & ++ & $-1-1-$ & 10 \\
\hline 11 & 60 & $\mathrm{~F}$ & A & WD & $\mathrm{RC}$ & ++ & $+1+1+$ & nd \\
\hline 12 & 62 & $M$ & A & WD & $\mathrm{RC}$ & + & $-1-1-$ & 5 \\
\hline 13 & 45 & $\mathrm{~F}$ & B & WD & $\operatorname{Rec}$ & - & $+/$ nd/+ & 10 \\
\hline 14 & 73 & $M$ & B & WD & $\operatorname{Rec}$ & nd & nd & nd \\
\hline 15 & 60 & M & B & WD & $\operatorname{Rec}$ & - & $+1+1+$ & 5 \\
\hline 16 & 86 & $\mathrm{~F}$ & B & MD & $\operatorname{Rec}$ & + & $+1-1+$ & $<5$ \\
\hline 17 & 67 & M & B & WD & LC & + & $-1-1-$ & 25 \\
\hline 18 & 65 & $\mathrm{~F}$ & B & WD & LC & + & $-1-1-$ & $<5$ \\
\hline 19 & 70 & $M$ & B & WD & $\mathrm{RC}$ & + & $-1-1-$ & 25 \\
\hline 20 & 62 & $\mathrm{~F}$ & B & WD & $\mathrm{RC}$ & + & $-1-1-$ & 10 \\
\hline 21 & 78 & $\mathrm{~F}$ & B & WD & $\mathrm{RC}$ & \pm & $+1+1+$ & 25 \\
\hline 22 & 73 & M & B & WD & $\mathrm{RC}$ & + & $+1+1+$ & 10 \\
\hline 23 & 54 & $M$ & $\bar{C}$ & WD & Rec & + & $+1-1+$ & 10 \\
\hline 24 & 72 & $\mathrm{~F}$ & C & WD & $\operatorname{Rec}$ & - & $+1-1+$ & 5 \\
\hline 25 & 64 & $\mathrm{~F}$ & C & WD & $\operatorname{Rec}$ & + & $-1-1-$ & $<5$ \\
\hline 26 & 65 & $\mathrm{~F}$ & C & UD & $\operatorname{Rec}$ & + & $+1-1+$ & 5 \\
\hline 27 & 55 & M & C & WD & $\operatorname{Rec}$ & + & $+1+1+$ & 5 \\
\hline 28 & 71 & $\mathrm{~F}$ & C & WD & LC & - & $+1+1+$ & 10 \\
\hline 29 & 59 & $\mathrm{~F}$ & C & WD & LC & + & $+1+1+$ & 5 \\
\hline 30 & 74 & $\mathrm{~F}$ & C & WD & LC & nd & nd & nd \\
\hline 31 & 77 & $\mathrm{~F}$ & C & WD & LC & + & $+1+1+$ & 10 \\
\hline 32 & 48 & $\mathrm{~F}$ & C & WD & LC & + & $-1-1-$ & $<5$ \\
\hline 33 & 66 & $\mathrm{~F}$ & C & WD & LC & - & $-1-1-$ & 25 \\
\hline 34 & 59 & $\mathrm{~F}$ & C & WD & LC & + & $+/$ nd/ + & 50 \\
\hline 35 & 70 & M & C & MD & LC & + & $+1+1+$ & 5 \\
\hline 36 & 28 & M & C & WD & $\mathrm{RC}$ & + & $+1+1+$ & 10 \\
\hline 37 & 84 & $\mathrm{~F}$ & C & UD & $\mathrm{RC}$ & - & $-1-1-$ & 5 \\
\hline 38 & 56 & M & C & UD & $\mathrm{RC}$ & ++ & $+1+1+$ & 5 \\
\hline 39 & 71 & M & C & WD & $\mathrm{RC}$ & \pm & nd & 25 \\
\hline 40 & 75 & $\mathrm{~F}$ & C & WD & $\mathrm{RC}$ & + & $-1-1-$ & 5 \\
\hline 41 & 65 & $\mathrm{~F}$ & C & WD & $\mathrm{RC}$ & + & $-1-1-$ & $<5$ \\
\hline 42 & 68 & $M$ & D & WD & Rec & + & $+1-1+$ & 5 \\
\hline 43 & 77 & $\mathrm{~F}$ & D & WD & $\operatorname{Rec}$ & \pm & $+1+1+$ & 25 \\
\hline 44 & 53 & $\mathrm{~F}$ & D & MD & $\operatorname{Rec}$ & + & $+1-1+$ & $<5$ \\
\hline 45 & 71 & $\mathrm{~F}$ & D & MD & $\operatorname{Rec}$ & nd & nd & nd \\
\hline 46 & 76 & M & D & MD & $\operatorname{Rec}$ & nd & nd & nd \\
\hline 47 & 74 & $\mathrm{~F}$ & D & WD & $\operatorname{Rec}$ & - & $-1-1+$ & 10 \\
\hline 48 & 75 & M & D & WD & $\operatorname{Rec}$ & nd & & nd \\
\hline 49 & 75 & $\mathrm{~F}$ & D & WD & $\operatorname{Rec}$ & - & $+1+1+$ & 5 \\
\hline 50 & 74 & M & D & WD & LC & nd & & nd \\
\hline 51 & 71 & $\mathrm{~F}$ & D & MD & LC & - & $+1+1-$ & nd \\
\hline 52 & 69 & M & D & WD & LC & - & $+1+1+$ & 5 \\
\hline 53 & 62 & $M$ & D & WD & LC & + & $-1-1-$ & $<5$ \\
\hline
\end{tabular}

F, female; M, male; nd, not determined; Rec, Rectum; LC, left colon; RC, right colon.

* Stage according to Dukes' classification. †Grade is degree of differentiation: HD, hyperdifferentiated; WD, well differentiated; MD, moderately differentiated; UD, undifferentiated. ‡EGF-R: semiquantitative immunohistochemical detection (ab-2): ++ , high levels; + , moderate levels; \pm , low levels; -, negative, § P53: positive (+) or negative (-) immunohistochemical detection of the apoptotic protein P53 mutations with 3 monoclonal anti-P53 antibodies (MAB 1801; MAB 240; DO7, ab-1). \# Ki67: percentage of positive nuclei.

colorectal cancers. Interestingly, the high frequency of hsst 5 expression was retained in advanced tumors.

No correlation was found between tumor characteristics and immunohistological markers except for P53 mutation which was more frequent in the rectum and the left colon than in the right colon. Moreover, no correlation could be observed between the tumor markers and the hsst mRNAs expression. Some 


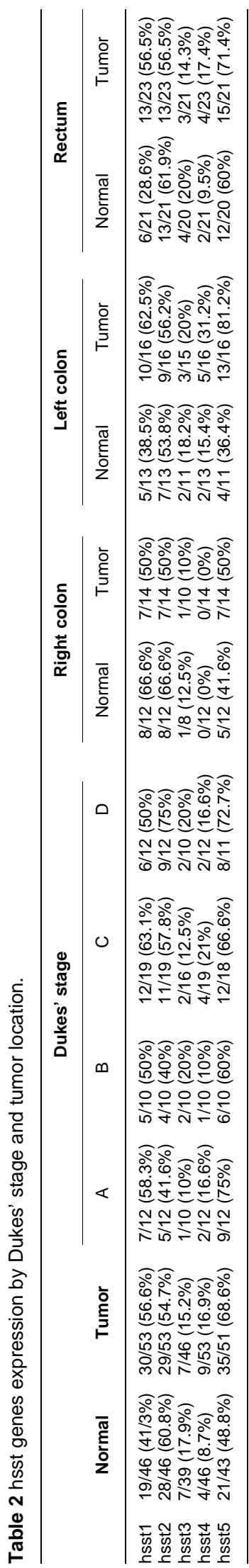

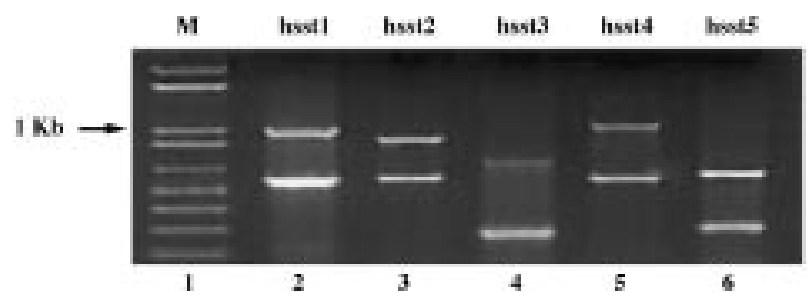

Figure 1 Ethidium bromide stained gel of a representative RT-PCR assay of the five sst receptors from colon carcinoma mRNA samples. RT-PCR products were separated in 1\% agarose gel. Lane 1 corresponds to $1 \mu \mathrm{g}$ DNA marker: $1 \mathrm{~Kb}$ plus DNA ladder (Life Technologies). Lanes 2, 3 and 5 correspond to hsst 1 (993 bp), hsst2 (892 bp) and hsst4 (1035 bp) respectively, co-amplified with a $549 \mathrm{bp}$ fragment of the cyclophilin gene. Lanes 4 and 6 correspond to hsst3 (653 bp) and hsst5 (581 bp) respectively, co-amplified with a 349 bp fragment of the cyclophilin gene.

differences in the expression of hsst mRNAs were seen according to the origin of the tissue. We found that the frequency of hsst5 mRNA expression was significantly higher in tumors than in normal samples in the left colon: $81.2 \%(13 / 16)$ and $36.4 \%(4 / 11)$ respectively $(0.025>P>0.01)$. In normal colon, we found that hsst1 mRNA expression decreased throughout the right colon, left colon and rectum and was significantly higher in right colon than in rectum: $66.6 \%(8 / 12)$ and $28.6 \%(6 / 21)$ respectively $(0.05>P>0.025)$. The frequency of hsst4 mRNA detection was low in left colon and rectum. hsst 4 mRNA was below the level of detection in right colon. Larger series will be useful to confirm these results.

\section{Discussion}

Looking for the pathophysiological bases for treatment of colorectal cancer with SS analogs, we found that the five hsst mRNAs were expressed in normal and pathological colon, with hsst5, hsst2 and hsst1 mRNAs being the most frequently expressed. The mRNA coding for hsst5, the receptor displaying a better binding selectivity for SS-28, was frequently found in colic tissue, in which SS-28 is predominantly synthesized. Using RT-PCR, Buscail et al. (13) have previously noted this very frequent expression of hsst5 mRNA in tumors (71\% of tumors whatever the stage). Laws et al. (14) also found an increased frequency of hsst5 mRNA expression in early stage tumors as compared with normal mucosa $(75 \%$ vs $45 \%)$. This increase in frequency was lacking in late stage tumors. Our findings showing that hsst5 mRNA was more frequently expressed in tumors, even those in Dukes' stages C and $\mathrm{D}$, than in normal tissues underlines the importance of hsst 5 in pathological colonic processes. These observations are interesting in view of the results of Cordelier et al. (18) who have demonstrated that hsst5 expressed in Chinese hamster ovary cells mediates the antiproliferative effects of SS analogs by inhibition of 
soluble guanidylate cyclase, protein kinase G, and p42 MAP kinase activities. Moreover, these antiproliferative effects of hsst5 were described using cholecystokinin (CCK)-stimulated cells. Interestingly, we have previously shown the existence of CCK-B long and short isoforms and $\mathrm{CCK}-\mathrm{C}$ receptors in the tumors analyzed in the present study (19).

Previously, Buscail et al. (13) have shown that hsst2 frequency of expression decreased with the tumor stage $(3 / 6,1 / 5$, or $0 / 3$ in Duke's stages $B, C$, and D respectively). Using RT-PCR and in situ hybridization, Laws et al. (14) have found that hsst 2 mRNA was widely distributed in normal mucosa and stroma in 90\% of samples. We found that hsst 2 mRNA was expressed at a high frequency throughout all tumor stages without any decrease of expression in advanced stage tumors.

Our results suggest that the recently described SS analogs, particularly those specific to hsst5, could be considered as possible treatments even in advanced stages of colorectal cancer. However, immunohistological studies with specific antibodies are needed to confirm the presence of sst proteins.

\section{Acknowledgements}

This work was supported by grants from the Programme Hospitalier de Recherche Clinique UF 2787.

\section{References}

1 Lewin MJM. The somatostatin receptor in the GI tract. Annual Review of Physiology 199254 455-468.

2 Lamberts SWJ, Krenning EP \& Reubi JC. The role of somatostatin receptors and its analogs in the diagnosis and treatment of tumors. Endocrine Reviews 199112 450-482.

3 Patel YC. Molecular pharmacology of somatostatin receptor subtypes. Journal of Endocrinological Investigation $199720348-$ 367.

4 Gouyon BA, Reyl-Desmars F, Le Romancer M, Pigeon C, Lewin MJM \& Lehy T. In vivo effect of somatostatin analogue, lanreotide, and/or GRP antagonist, BIM 26226, on the growth of colon cancer peritoneal carcinomatosis in the rat. International Journal of Oncology 19957 1167-1173.

5 Qin Y, Shally AV \& Willems G. Treatment of liver metastases of human colon cancers in nude mice with somatostatin analogue RC-160. International Journal of Cancer 199252 791-796.
6 Goldberg GM, Moertel CG, Wiehand HS, Krook JE, Schutt AJ, Veeder $\mathrm{MH}$ et al. A phase III evaluation of a somatostatin analogue (octreotide) in the treatment of patients with asymptomatic advanced colon carcinoma. Cancer $199576962-966$.

7 Cascinus S, Del Ferro E, Grianti C, Ligi M, Ghiselli R, Foglietti G et al. Inhibition of tumor cell kinetics and serum insulin growth factor I by octreotide in colorectal patients. Gastroenterology 1997 $113767-772$

8 Florio T \& Schettini G. Multiple intracellular effectors modulate physiological function of the cloned somatostatin receptors. Journal of Molecular Endocrinology 199617 89-100.

9 Radulovic SS, Milovanovic SR, Cai RZ \& Shally AV. The binding of bombesin and somatostatin and their analogs to human colon cancers. Proceedings of the Society for Experimental Biology and Medicine $1992200394-401$.

10 Reubi JC. Horisberger U \& Laissue J. High density of somatostatin receptors in veins surrounding human cancer tissue: role in tumorhost interaction. International Journal of Cancer 199456 681-688.

11 Iftikhar SY, Thomas WM, Rooney PS \& Morris DL. Somatostatin receptors in human colorectal cancer. European Journal of Surgical Oncology $19921827-30$.

12 Reubi JC, Horisberger U, Waser B, Gebber JO \& Laissue J. Preferential location of somatostatin receptors in the germinal centers of human gut lymphoid tissue. Gastroenterology 1992103 1207-1214.

13 Buscail L, Saint-Laurent N, Chastre E, Vaillant J-C, Gespach C, Capellà $\mathrm{G}$ et al. Loss of sst 2 receptor gene expression in pancreatic and colorectal cancer. Cancer Research 199656 1823-1827.

14 Laws S, Gough AC, Evans AA, Bains MA \& Primerose JN. Somatostatin receptor subtype mRNA expression in human colorectal cancer and normal colonic mucosa. British Journal of Cancer 199775 360-366.

15 Dukes CE \& Bussey HJR. The spread of rectal cancer and its effect on prognosis. British Journal of Cancer 1958 12 309-320.

16 Chomczynski P \& Sacchi N. Single-step methods of RNA isolation by acid guanidinium thiocyanate-phenol-chloroform extraction. Analytical Biochemistry 1987162 156-159.

17 Dutour A, Kumar U, Panetta R, Ouafik L, Fina F, Sasi R et al. Expression of somatostatin receptor subtypes in human brain tumors. International Journal of Cancer 199876 620-627.

18 Cordelier P, Estève J-P, Bousquet C, Delesque N, O'Carroll A-M, Shally AV et al. Characterization of the antiproliferative signal mediated by the somatostatin receptor subtype sst5. Proceedings of the National Academy of Sciences of the USA 199794 9343-9348.

19 Biagini P, Monges G, Vuaroqueaux V, Parriaux D, Cantaloube F \& De Micco P. The human gastrin/cholecystokinin receptors: type B and type $C$ expression in colonic tumors and cell lines. Life Sciences $1997611009-1018$.

Received 26 August 1998

Accepted 2 December 1998 